\title{
Dr. Nigel Rusted, a CMAJ centenary reader
}

I n 1911, the 22-year-old Maritime Medical News voluntarily folded to join the McGill Medical Journal in the new Canadian Medical Association Journal venture; that same year, the independent Halifax Medical College formally joined Dalhousie University as its Faculty of Medicine. ${ }^{1}$ Just four years earlier, a boy who would eventually attend Dalhousie medical school was born in the Newfoundland outport of Salvage. Dr. Nigel Rusted, who is quite likely $C M A J$ 's oldest reader today at 103 , provides a remarkable window on the journal's context as medicine evolved over the 20th century and on aspects of Newfoundland's and Canada's history.

Rusted's career encompassed early education in a self-governing Dominion and biennial self-funded trips to the mainland for continuing medical education; the entrance of Newfoundland into Confederation with Canada in 1949; and his subsequent connection with the Canadian Medical Association (CMA) and its journal. Of note, too, is his birth date: July 1 , which is both Canada Day and (in Newfoundland) Memorial Day. Within his profession, Rusted was known as an innovative surgeon and an academic leader in St. John's. After his retirement in 1987, at the age of 80 , his attention shifted from

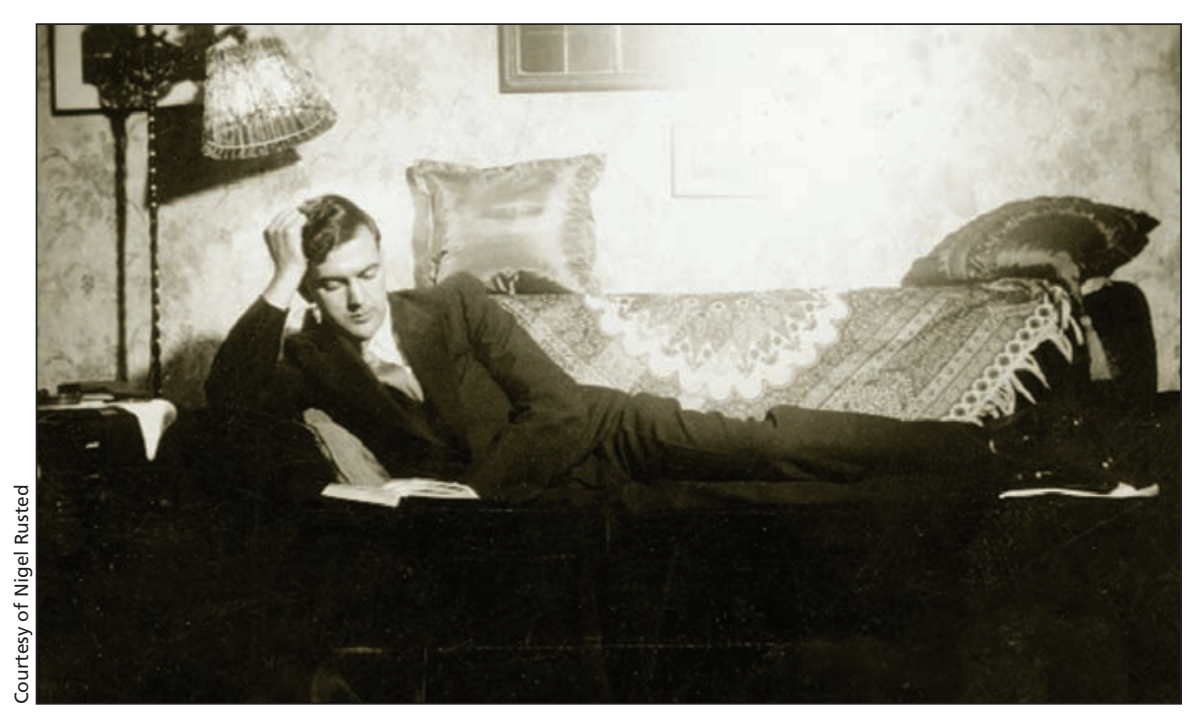

Rusted as an intern (final year of medical studies) in New Glasgow, Nova Scotia in 1932.

surgery and medical practice to medical humanities. Along the way, he encountered famous members of both fields in North America.

Rusted was born in Salvage, Newfoundland and spent his childhood in Upper Island Cove. At 16, he settled in St. John's for high school and college. The eldest of six, he has outlived all of his siblings, as well as his wife of 67 years, Florence (née Anderson). One brother, Ian, became a doctor and founded the medical school in St. John's. His other brother went into the ministry (like their father), worked overseas as a missionary, then eventually became Dean of the Anglican Cathedral in St. John's. Two sisters worked in nursing and the other was a high-ranking officer and dietitian with the Royal Canadian Air Force. Rusted and his wife (whose parents were a nurse and physician) had three children, three grandchildren, and two (soon to be three) great grandchildren. Of them, one has followed in Rusted's medical path, his granddaughter (coauthor AH).

Rusted was in the inaugural class of Memorial University College in St. John's, Newfoundland and received his diploma in arts and sciences in 1927. Rather than follow his father and

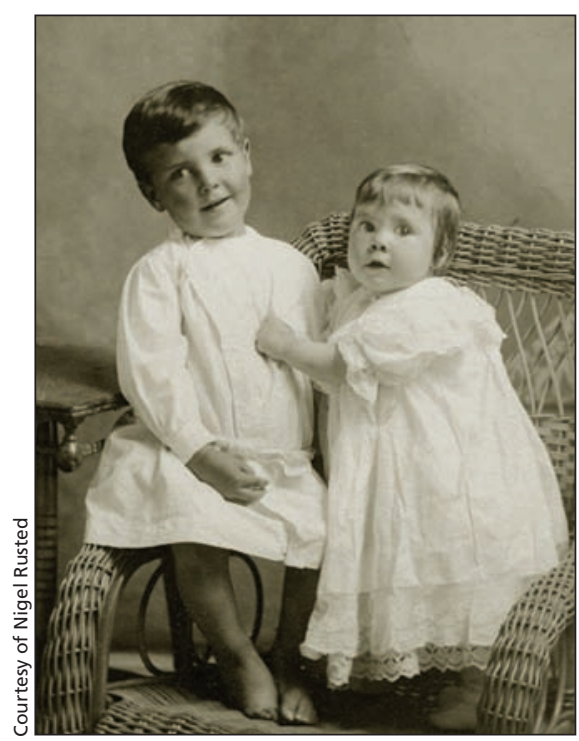

Dr. Nigel Rusted with his sister Winifred in 1910. Rusted was born in 1907 and is quite likely CMAJ's oldest reader today at 103.

maternal grandfather into the ministry, he was initially attracted to engineering, but opted for medicine owing to his friendship with a doctor in Harbour Grace and his familiarity with his father's practice of dispensing drugs in minor cases where no doctor was available (a common part of the minister's job in vast territories). ${ }^{2}$ While attending Dalhousie medical school in Halifax, Nova Scotia, Rusted served as health officer for two summers aboard the S.S. Kyle, which visited more than 50 communities along the Labrador coast. Norman H. Gosse, a Newfoundlander who became a prominent surgeon in Halifax and was a former health officer on the Kyle, tutored him for the task. ${ }^{3}$ On 12 return trips to Labrador from St. John's in 1930 and 1931, Rusted treated hundreds of patients in coastal communities and in the onboard "hospital," mainly for common ailments and injuries such as infected or crushed fingers, fractured legs and ribs (often a result of fishermen falling over the side of a boat). Given the lack of wharves, he went ashore only if the patient was immobile. ${ }^{4}$ In St. Anthony he met the famous medical missionary Sir Wilfred 


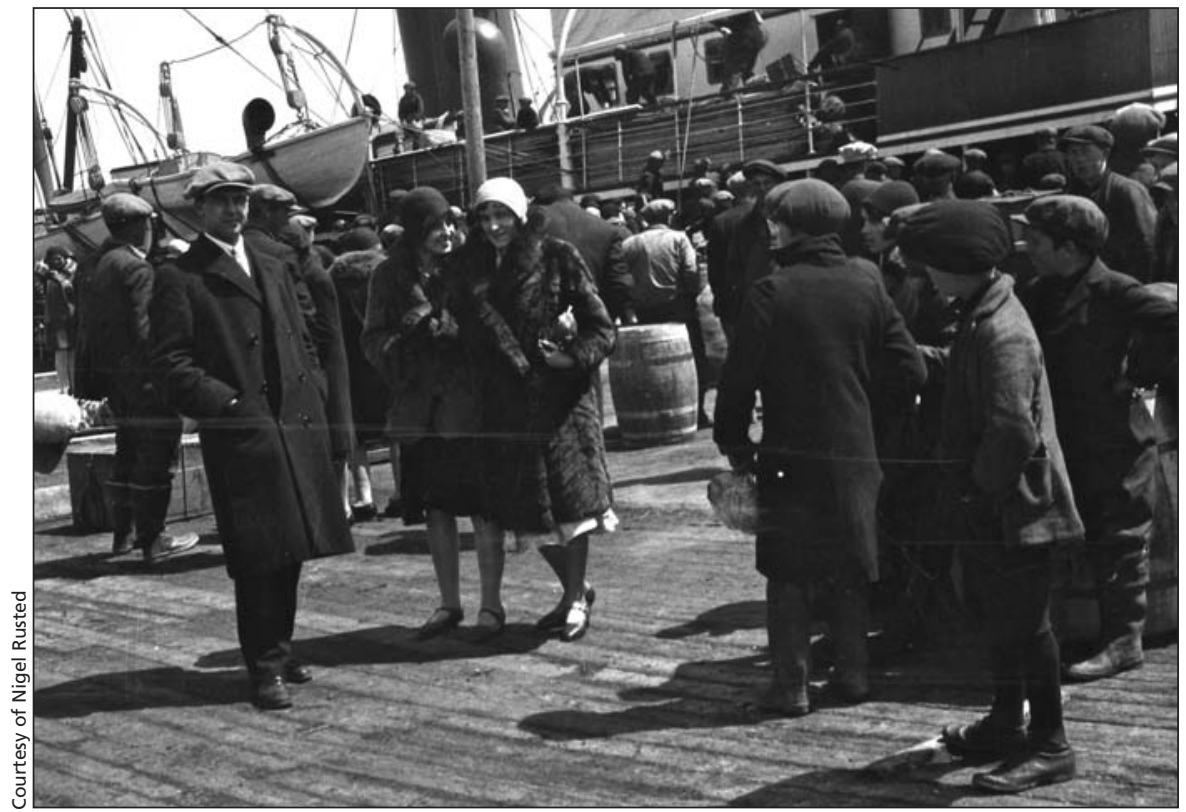

Rusted in Carbonear, Newfoundland, 1930, with the S.S. Kyle in the background. He served as health officer for two summers aboard the S.S. Kyle, which visited more than 50 communities along the Labrador coast.

Grenfell several times, and Rusted shuttled patients with more serious conditions among Grenfell hospitals and their homes on the route from St. Anthony to Battle Harbour.

For his fifth, and final year of medical studies, Rusted completed intern-

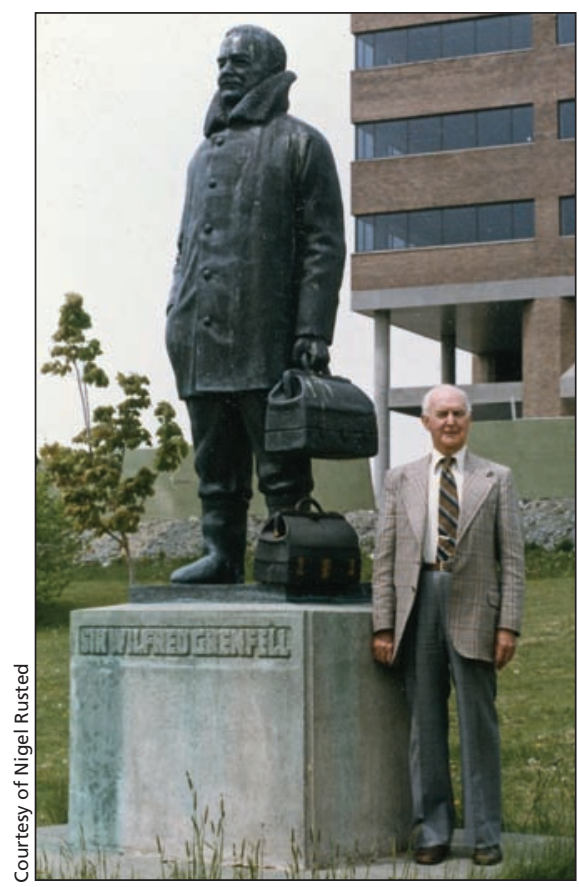

Rusted poses beside the statue of Sir Wilfred Grenfell outside Confederation Building in St. John's, Newfoundland in 1985. Rusted's bag was used as the model for Grenfell's bag in the statue. ships in Nova Scotia at the tuberculosis sanatorium in Kentville, Aberdeen Hospital in New Glasgow, and Victoria General Hospital in Halifax. Already on track to become a surgeon, he enjoyed many opportunities to operate and to observe operations. His 12 weeks with Frank Mack in urology were especially formative for Rusted, who became Mack's first assistant. Upon graduating in 1933, Rusted was offered numerous residency positions, including one in urology at Montréal's Royal Victoria Hospital and one in Syracuse, New York. He accepted a position for $\$ 60$ per month at the St. John's General Hospital (a better salary than elsewhere) because he wanted to come back and contribute to Newfoundland. As he recounts in his memoir, It's Devil Deep Down There, which is based on his diary entries, he had a challenging time for the next two years. When weekly coastal boats and biweekly trains arrived with patients at the hospital, he often performed three operations after midnight. Day to day, Rusted was responsible for the entire hospital's 150 patients. From June 1933 to December 1934, he assisted in 579 procedures and performed 332 himself. Infection was always a paramount concern in this pre-antibiotic era. Indeed, a severe infection of his

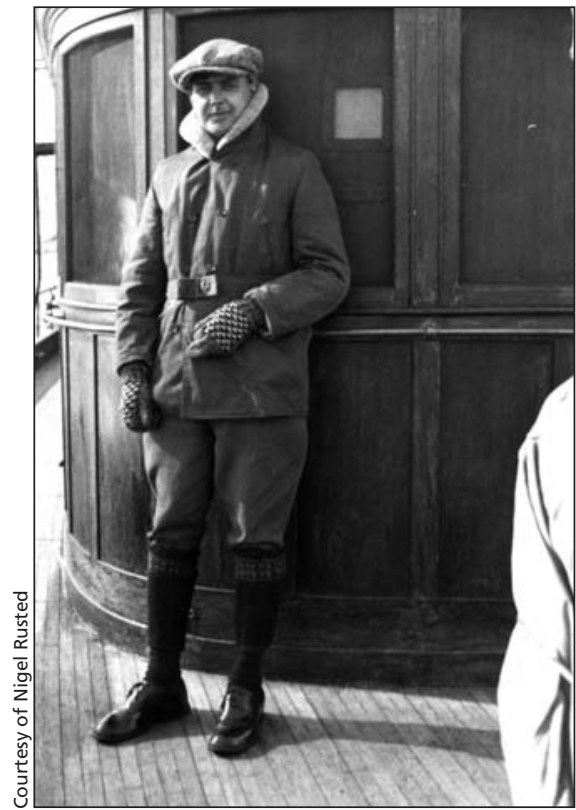

He was the first medical officer on the southwest Newfoundland coast travelling clinic aboard the M.V. Lady Anderson.

own throat and palate incapacitated him in early 1935 , leading to advice that he take a year away from hospital infections to build up his own health. This advice led to his appointment as the first medical officer on the southwest Newfoundland coast travelling clinic aboard the ship M.V. Lady Anderson. ${ }^{2}$

During his seven trips to the area in 1935-36, Rusted was responsible for the health care of people in about 80 coastal communities. He saw 3000 patients, performed 59 minor operations, gave 761 local anesthetics, 5 general anesthetics and extracted almost 2500 teeth. He also gave 112 inoculations for typhoid and countless smallpox vaccinations. Dental cases by far outnumbered all other conditions (180 in a two-month period alone); pulmonary tuberculosis (62) and tuberculosis of bone or glands (17) accounted for the next largest groups of cases. He became adept at diagnosing tuberculosis without the use of x-rays. But there were other medical needs as well. Rusted recalls his investigation of a suspected case of smallpox after Canadian immigration officials turned away a schooner from Newfoundland and quarantined the island. He visited every home in the schooner's point of departure, discovered a severe epidemic of chicken pox, not smallpox, that "looked 
nasty" and vaccinated most of the people for smallpox. The Canadian government lifted the quarantine after the Newfoundland government received his report. The Newfoundland Department of Health praised his job as demonstrating to Canadian authorities the "effectiveness and efficiency of our Floating Clinic Service.,",3

During Rusted's subsequent career in surgery, he worked and held executive positions at all four hospitals in St. John's (see Box 1). He made 25 educational trips around North America to observe such notable surgeons as Gordon Murray, William Gallie, Stuart Gordon, Fraser Mustard, Gavin Miller, Charles K.P. Henry, and Alfred T. Bazin (Bazin was a former CMA President and CMAJ's managing editor in the late 1920s). Rusted was the first to perform several operations in Newfoundland including partial gastrectomy, pedicle graft from abdomen to neck, adrenalectomy, and cleft lip and cleft palate repair. He became particularly well-known for the latter, performing 560 reconstructive surgeries. ${ }^{5}$ After retiring from surgery in 1982 at the age of 75 , he continued to perform travelling clinics for cleft lip and palate consultations. Decades later, he made notes about encounters with patients' grateful family members. In 2000,

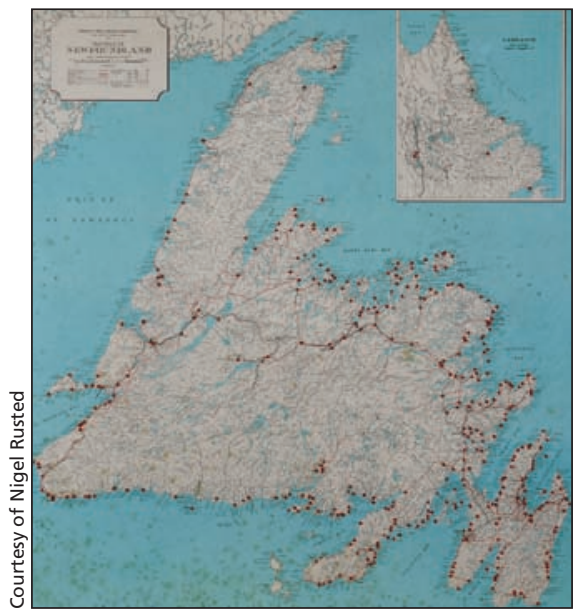

The pins indicate the towns of patients whom Rusted operated on; there were sometimes 20 patients from one place.

when he was in a store, a woman rushed over to thank him for repairing her mother's palate, "as otherwise she would not be here as her mother would have remained with her parents and never would have married."

In addition to his clinical responsibilities, Rusted served Memorial University on its first Board of Regents and its Building Committee. (It was his younger brother, Dr. Ian Rusted, who lobbied for a medical school at Memorial and became its first dean in 1969. ${ }^{6.7}$ ) Over the years Rusted received numerous honours, including the Order of

\section{Box 1: Dr. Nigel Rusted's career highlights}

- 1933: Joined the Newfoundland Medical Association

- 1936: Appointed Junior Surgeon at the St. John's General Hospital, and opened his private practice

- 1938-1939: Secretary, Newfoundland Medical Association

- 1938-1939: Chairman, St. John's Clinical Society

- 1943-1945: Chaired first clinical meetings at the St. John's General Hospital

- 1949-1966: Medical Director, Chief of Staff, and Chief Surgeon at the Grace General Hospital, St. John's

- 1951-1957: Elected to the first Board of Regents for Memorial University of Newfoundland when it achieved university status, and served on the Building Committee for the first four buildings on the new university site

- 1954-1968: Chief of Surgery at the St. John's General Hospital

- 1966-1982: Senior Consultant at all four hospitals in St. John's: St. John's General Hospital, St. Clare's Mercy Hospital, Grace General Hospital, and Janeway Child Health Centre

- 1968: Appointed Clinical Professor of Surgery, with the opening of Memorial University's medical school

- 1970s: Newfoundland representative to CMA council, and meetings in Winnipeg, Banff, Montréal, Toronto, and Halifax

- 1982: Retired from surgery (age 75)

- 1987: Retired from clinical practice

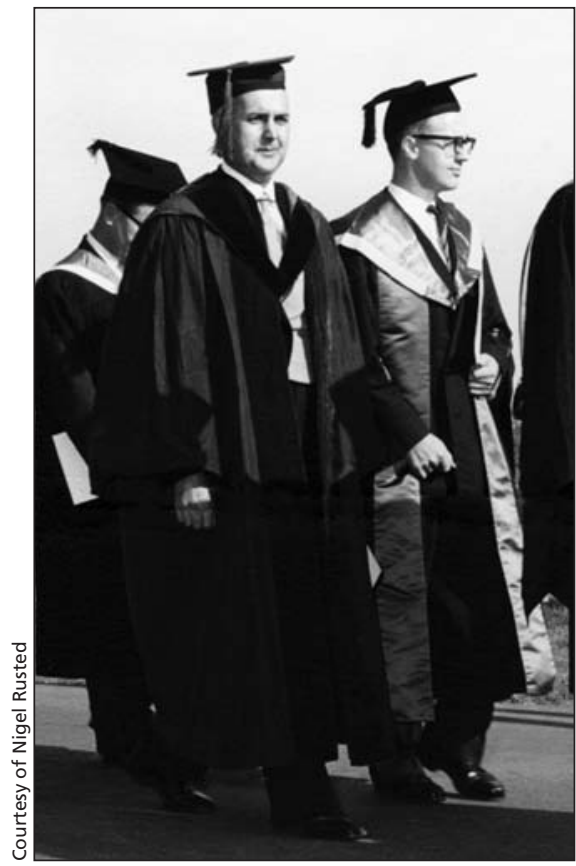

Rusted in an academic procession to open the "new" Memorial University campus, 1961. Beside him is his brother, Dr. Ian Rusted, who lobbied for and founded the Faculty of Medicine.

Newfoundland and Labrador and the first William B. Spaulding Certificate of Merit for contribution to the history of medicine in Canada (see Box 2). The latter award was in part recognition for his memoir ${ }^{2}$ and his historical survey, The Physicians and Surgeons: Biographical Gleanings. ${ }^{8}$ Publishing highlights in his career also include an acknowledgement in The Cod Fisheries, by renowned economic historian Harold A. Innis, whom Rusted first met during one of Innis's trips as a tourist aboard the S.S. Kyle.

Rusted first encountered the CMA as a medical student in October 1928. The annual meeting had been held in Charlottetown, Prince Edward Island, and the Medical Society of Nova Scotia hoped to attract CMA delegates to Halifax afterward for its 75th annual meeting. Rusted recalls hearing noted Canadian pathologist William Boyd speak, along with the Montréal-based surgeon Sir Henry Grey. ${ }^{2,10}$ In those days, the CMA struggled to obtain members nationally and encouraged federation with provincial societies as CMA branches (later called divisions). ${ }^{11}$ Rusted joined the CMA when Newfoundland became the tenth province of 


\section{Box 2: Dr. Nigel Rusted's honours}

- 1950: Fellow of the American College of Physicians and Surgeons

- 1950: Fellow of the International College of Surgeons

- 1973: Honorary DSc, Memorial University of Newfoundland (coinciding with the first graduating class in medicine)

- 1974: Fellow of the Royal College of Physicians and Surgeons of Canada

- 1974: Senior Membership, CMA

- 1986: Nigel Rusted Lectureship on the History of Surgery, founded by Discipline of Surgery, Faculty of Medicine, Memorial University of Newfoundland

- 1996: William B. Spaulding Certificate of Merit for contribution to the history of medicine in Canada, awarded by Associated Medical Services, Toronto

- 2007: Order of Newfoundland and Labrador

- 2008: Freedom of the City of St. John's

- 2010: Life Membership, Newfoundland and Labrador Medical Association

- 2010: Honorary Patron, [Alumni] Memorial on Parade: Celebrating from 1925 to 1961

Canada in 1949. Newfoundland figured immediately in CMAJ pages in a follow-up survey of nutrition: "At one time off the beaten track, scarcely known to outsiders," wrote the mostly American authors, "Newfoundland was catapulted into a new position" as an international crossroads during the war. ${ }^{12}$ The Newfoundland Medical Association voted unanimously to apply for divisional status within the Canadian society, and so Newfoundland held unusual status at the 1949
CMA meeting in Saskatoon, as both part of Canada, with a divisional representative, and as equal to Canada in the first British Commonwealth Medical Conference hosted at the same time. ${ }^{11}$ CMA membership in Newfoundland grew immediately to 98 in $1950 . .^{13,14}$ That year, Norman H. Gosse, Rusted's mentor at Dalhousie, became CMA president. Rusted later acted as Newfoundland representative to the CMA, and he recalls meetings in Winnipeg, Banff, Montréal, Toronto, and Halifax.

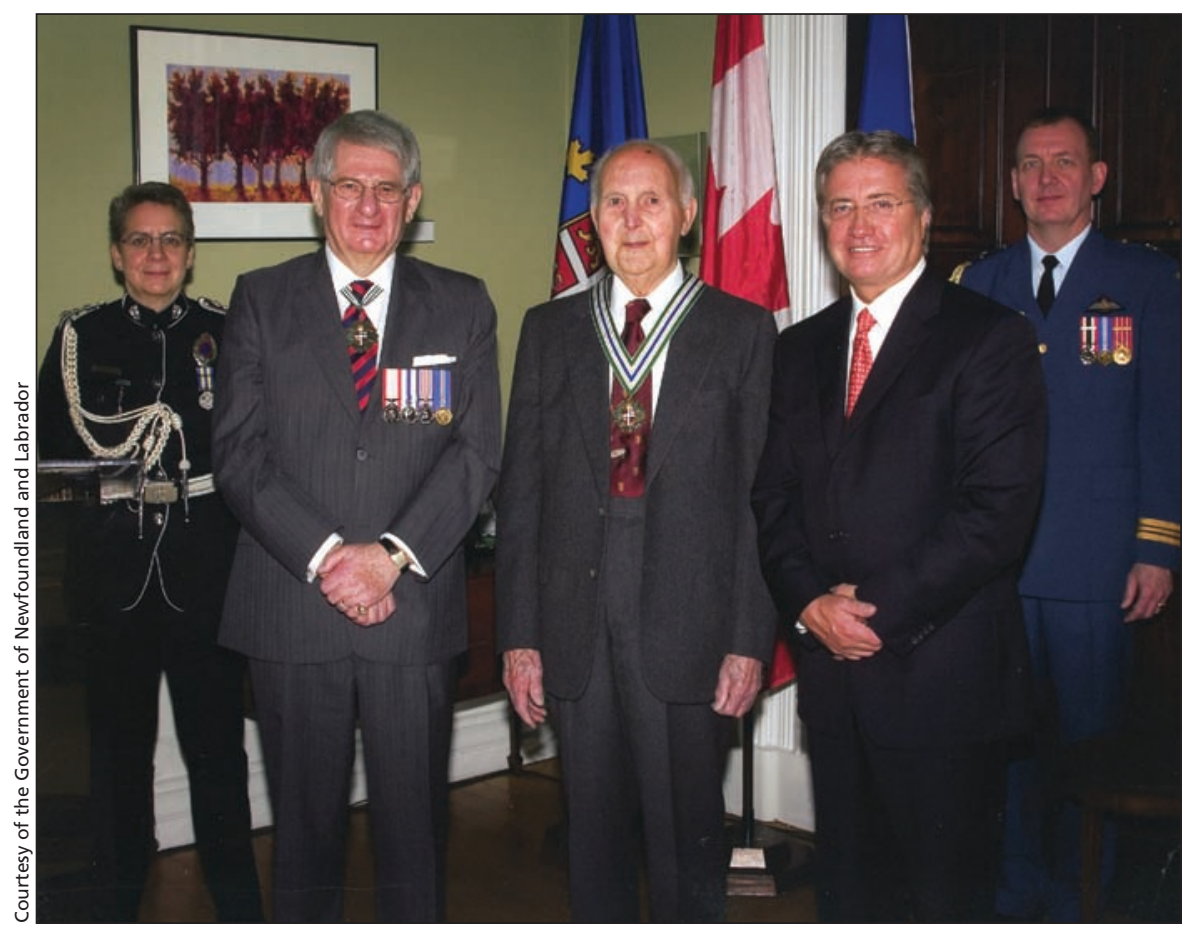

Rusted received the Order of Newfoundland and Labrador a few months after his 100th birthday. On his left, then-Premier Danny Williams; on his right, then-LieutenantGovernor Edward Roberts, who as minister of health had been involved in the early years of the province's medical school.
Like others of an earlier generation in medicine, such as William Boyd ${ }^{15}$ Rusted kept diaries and notebooks about his practice and thoughts on medicine; he continues to keep the daily diary he began on Jan. 1, 1925. His notebooks contain retrospective essays that he drew upon for publications and interviews; in one unpublished note "Medicine 70 Yrs Ago," for instance, he summarized the common illnesses when he began practice in the era before antibiotics: pneumonia, tuberculosis, syphilis, and gonorrhea. He is still a voracious reader, particularly of medical nonfiction books and studies in medical history in addition to CMAJ. As he is known for holding strong opinions on various topics, past and current, it is no wonder that Rusted's own views are frequently sought and published in histories of Newfoundland. ${ }^{3,4,16,17}$

Rusted continues to stay abreast of recent developments in medicine with his reading: CMAJ is always at the top of his reading pile by the fireplace in his home. After years of reading Surgical Clinics of North America, Surgery Gynecology and Obstetrics, and the International Journal of Surgery, he now reads only the CMAJ. He looks through the entire issue and reads "everything that looks interesting." $\mathrm{He}$ makes a point to read the obituaries. He has now outlived all of his Dalhousie classmates and all of the pioneers in medicine that he once travelled to see, so it is not surprising that he no longer recognizes the obituary names. He wryly commented that $C M A J$ cancelled his own subscription in recent years, until he followed up and found out that someone thought he had died.

In conversation, Rusted rarely wonders about medical innovations that would have aided his practice, although he notes that antibiotics clearly "would have saved a lot of lives" if they'd been available earlier. But he routinely laments some negative changes in the practice of medicine, such as too much reliance on technology and loss of authority (or respect) in the profession. For him, the diminished emphasis on the humanities seems to play a role in these latter changes. When asked what "humanities" means to him, he sug- 


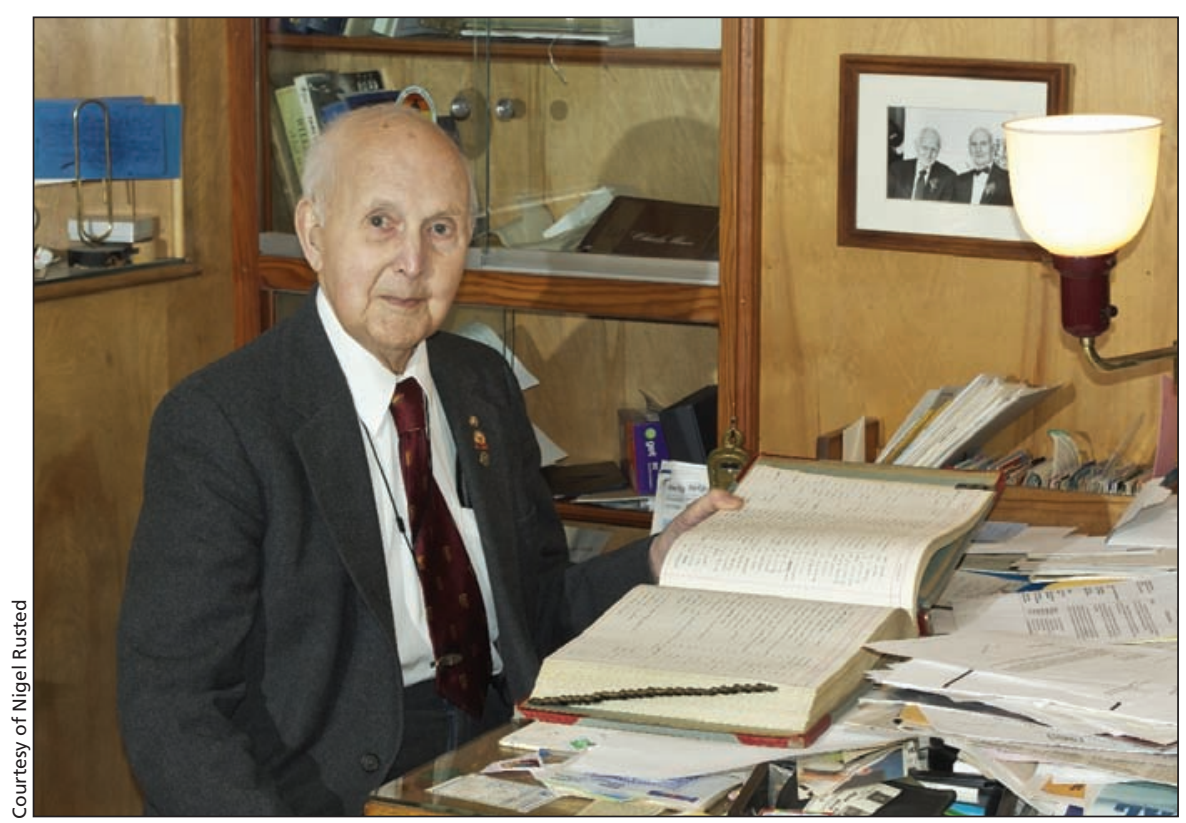

In this December 2010 photograph, Rusted sits in his office at home where he used to see patients, with one of the log books listing details of the surgeries he performed.

gested that today "education is pretty limited to lectures on medicine, not much else"; and that humanities should "broaden the outlook of students," by offering "more of a general education" to "expand the knowledge of the student" - basically, "anything outside the study of drugs and medical lectures." His passion prompted him to launch in 2004 the Dr. Nigel Rusted Lectureship in Medical Humanities, which he continues to sponsor annually. ${ }^{18,19}$ The occasion is a chance for Rusted to test medical students about their knowledge of medicine, while gently chiding them at dinner about appropriate conversational behaviour and manners. He also loves to quiz his granddaughter (coauthor $\mathrm{AH}$ ), a medical and doctoral student in genetics, especially on the topic of "DNA." Of course, DNA was not discovered until well into his career, yet he has bridged the generation gap owing to almost 80 years' difference in medical training between himself and that of his granddaughter through his continued reading of CMAJ.

\section{Jennifer J. Connor PhD}

Medical Humanities

Discipline of Psychiatry

Faculty of Medicine

Angela J. Hyde BSc (Hons)

$\mathrm{PhD}$ class of 2011

MD class of 2013

Faculty of Medicine

Memorial University of Newfoundland St. John's, NL

\section{References}

1. McPhedran NT. Canadian medical schools: two centuries of medical history, 1822 to 1992 . Toronto (ON): Harvest House; 1993. p. 119.

2. Rusted N. It's devil deep down there: 50 years ago on the M.V. Lady Anderson, a mobile clinic on the S.W. coast of Newfoundland. 2nd ed. St. John's (NL): Creative; 1987.

3. MacLeod M, ed. Nigel Rusted In: Crossroads country: memories of pre-Confederation New- foundland. St. John's (NL): Breakwater Books; 1999. p. 26-41.

4. McKinnon I. A health and medical services perspective of the Labrador fishery from an oral history interview with Dr. Nigel Rusted [transcript]. Memorial University Folklore and Language Archive, MS 86-120, F13821c-12822c, 1986 Mar. 26, Memorial University, St. John's (NL).

5. Dr. Nigel Rusted receives honorary life membership award. Nexus Online. [Newfoundland and Labrador Medical Association Newsletter]. Summer 2010. Available: www.nlma.nf.ca/nexus/issues /summer_2010/articles/article_1.html (accessed 2011 Jan. 24).

6. A commemoration of our first 40 years. St. John's (NL): Faculty of Medicine, Memorial University of Newfoundland; [2007]. Available:www.med.mun .ca/earlydays/pages/10_40th_anniversary/40thYearbook07.pdf (accessed 2011 Mar. 21)

7. The early days of the medical school, Memorial University of Newfoundland. [digital exhibit.] St. John's (NL): Memorial University of Newfoundland. Available: www.med.mun.ca/earlydays/ (accessed 2010 Nov. 29).

8. Rusted N. The physicians and surgeons: biographical gleanings. St. John's (NL): Memorial University of Newfoundland, Faculty of Medicine; 1994.

9. Innis HA. The cod fisheries: the history of an international economy. New York (NY): Carnegie Endowment for International Peace; 1940.

10. The Medical Society of Nova Scotia. NS Med Bull 1928:7:437-76.

11. MacDermot HE. History of the Canadian Medical Association. Volume II. Toronto (ON): Murray; 1958.

12. Aykroyd WR, Joliffe N, Lowry OH, et al. Medical resurvey of nutrition in Newfoundland 1948. Can Med Assoc J 1949;60:330-52; 331.

13. The eightieth annual meeting of the Canadian Medical Association: Business reports. Can Med Assoc J 1949;61:205-40.

14. The eighty-first annual meeting of the Canadian Medical Association: Business reports. Can Med Assoc J 1950;63:211-36.

15. Carr I. William Boyd - the commonplace and the books. Can Bull Med Hist 1993;10:77-86.

16. Sullivan JM. Interview with Dr. Nigel Rusted. Newfoundland Quarterly 2007;100(1):7-8.

17. Rusted N. Memorial College 1925-26. Luminus[Memorial University of Newfoundland Alumni Magazine] 2010;34(2):36.

18. Inside the dissection room. [JM Edmonson; Dr. Nigel Rusted Lectureship in Medical Humanities 2010]. St. John's (NL): Memorial University of Newfundland, News at Medicine; Nov 2010. Available: www.med.mun.ca/Medicine/News Medicine/November-2010/Inside-the-dissection-room.aspx (accessed 2010 Nov. 29).

19. Illness in national leaders affects world events. [J Murray; Dr. Nigel Rusted Lectureship in Medical Humanities 2004]. St. John's (NL): Memorial University of Newfoundland, MUNMed 2004 16(2). Available: www.med.mun.ca/MUNMED/munmedNews/32/pages/murray_jock.htm (accessed 2011 Jan. 19).

CMAJ 2011. DOI:10.1503/cmaj.101858 